\title{
Jokowinomics: A New Developmentalism with Rising Skyscrapers and Sinking Indonesian Civil Rights Liberty
}

\author{
Cheryl Pangestu \\ Parahyangan Catholic University \\ cherylpangestu@gmail.com
}

\begin{abstract}
Abstrak
Presiden Joko Widodo masih memiliki fokus yang sama - bahkan lebih intens - dalam periode kedua kepresidenannya terkait dengan pembangunan ekonomi. Jokowinomics, yang menjadi jargon model pembangunan ala Presiden Joko Widodo seringkali dipamerkan sebagai prestasi nasional untuk memenangkan hati konstituen melalui gedung pencakar langit, jembatan penghubung dan transportasi umum modern. Pendekatan teknokratik dan pragmatis ini disebut oleh dunia akademisi sebagai bentuk 'new developmentalism'. Tulisan ini akan membuktikan bahwa agenda pembangunan materialistis dengan Jokowinomics terlalu sempit untuk menjawab tantangan pemenuhan hak-hak sipil warga negara Indonesia, sebagaimana yang tertuang dalam cakupan agenda no.16 Sustainable Development Goals yang dicanangkan oleh United Nations Development Program (UNDP). Ledakan pembangunan infrastruktur di era kepresidenan Joko Widodo dibarengi dengan dikeluarkannya Undang-Undang yang represif terhadap minoritas tertentu, pelemahan beberapa institusi penopang keadilan, hingga pembatasan kebebasan pers kemudian menjadi kontradiksi dalam pembangunan yang seharusnya menyejahterakan dan memerdekakan masyarakat sipil. Dengan menggunakan konsep 'development as freedom' oleh Amartya Sen, tulisan ini menawarkan untuk mengevaluasi implikasi dari implementasi Jokowinomics terhadap pemenuhan hak sipil untuk mencapai pembangunan yang bersifat inklusif dan berkelanjutan. Tulisan ini kemudian akan esensial sebagai studi kasus pembangunan negara berkembang yang saat ini masih didominasi oleh narasi neoliberal pragmatis yang pada akhirnya kurang mengindahkan usaha pemenuhan hak-hak sipil.
\end{abstract}

Kata Kunci: Jokowinomics, Sustainable Development Goals no.16, Just Development, Hak Sipil. 


\section{Introduction}

The $16^{\text {th }}$ agenda of Sustainable Development Goals (SDGs) covers mostly on the importance of human basic and civil rights that is later specified into the perspective of individual rights and a wider approach in the form of an institutional basis. On the individual level, the $16^{\text {th }}$ agenda stresses upon the need to ensure the rights to live, to be free from whatever form of torture, the rights to obtain information, access to political participation, and the rights to legal personality and justice. ${ }^{1}$ While institutionally, the $16^{\text {th }}$ agenda points out the need to build an effective institution, mostly referring to state and its subordinates, that are inclusive and accountable which particularly relates to democratic, nondiscriminatory and anti-corruption government. ${ }^{2}$ Indonesia has already committed to achieve SDGs by the end of 2030 through a Presidential Decree that enacts as the legal basis to incorporate the goals into the national vision and by the establishment of a National Coordination Team placed under the direct coordination of the President. ${ }^{3}$ That being said, the development plan is supposed to implement the indicators needed to realize the world envisioned by the global framework to be translated into a peaceand-justice-oriented development plan.

'Infrastructure' and 'fast growth' seem to be the most familiar buzzwords when President Joko Widodo (or more popularly known as "Jokowi") laid out his plan for national development. In his first presidential campaign before securing his seat in 2014, Jokowi had shown ambitions in reviving the economic growth, promising a 7\% growth by the end of $2019 .{ }^{4}$ Although he failed to deliver and only reached $5.2 \%$ of growth by the end of his first term, Jokowi had always seemed to defend his infrastructure boom as the top priority for building Indonesia, which is evident when Prabowo, a longtime political rival criticized him in the 2019 presidential debate about how little and disproportionate Indonesia's defense budget is in comparison to other neighboring countries including Singapore. ${ }^{5}$ In response to such criticisms, Jokowi tended to give a nuanced answer on acknowledging other needs, but infrastructure has to be one of the top concern and main budget allocation. His achievement in building highways, bridges, electricity and water infrastructures was also rarely absent in his re-election bid campaign in winning the hearts of the national constituents. So, when he secured his second term after a tight competition with Prabowo, it was no longer surprising when Jokowi became even more explicit with his economic ambitions by aiming to cut bureaucratic red tapes, inviting as many foreign

\footnotetext{
${ }^{1}$ Komnas HAM, “Tujuan 16," in Kerangka Analisis untuk Mengintegrasikan Tujuan Pembangunan Berkelanjutan (SDGs) dengan Kewajiban Pemenuhan Hak-hak Asasi Manusia untuk di Indonesia, available in komnasham.go.id

2 "Progress of Goal 16 in 2019," SDG Knowledge Platform, https://sustainabledevelopment.un.org/sdg16

3 "Indonesia's Commitment to Sustainable Development: 2030 Agenda for Sustainable Development,"

Kementrian Luar Negeri Republik Indonesia, https://indonesia4unsc.kemlu.go.id/index.php/ourpriorities/indonesia-s-commitment-to-sustainable-development

${ }^{4}$ Timothy Cheston, "Indonesia and the Quest for 7\% Growth: Overpromise or Underperformance?" Atlas of Economic Complexity Harvard, https://atlas.cid.harvard.edu/stories/indonesia/

${ }^{5}$ Jokowi nuanced response in verbatim: "We all agree we need to increase our defence budget. But we must have priorities. For now, it is infrastructure". Read more on Peter McCawley, 2019, "Jokowi bets on an infrastructure boom," East Asia Forum, April 10, https://www.eastasiaforum.org/2019/04/10/jokowi-bets-onan-infrastructure-boom/
} 
investments as possible, opening doors to capital and jobs; all to create an independent Indonesia so it can become one of the top 5 world economy. ${ }^{6} \mathrm{He}$ also straightforwardly promised the people, in his second inaugural speech, to obstruct anything that stands in the way of the infrastructure development and people's jobs. ${ }^{7}$ Such firm stance on economy and his leadership overall is a sufficient telling that infrastructure and fast economic growth will play a central part on how he is going to spend the rest of his five years incumbency. This signature approach then was branded as Jokowinomics as its identifier. Seeing that the trajectory for Jokowinomics in the second term will most likely follow the path of the first one, it is urgent to assess on whether the approach is strategic enough for Indonesian development's sustainability.

Notably, this style and orientation has been previously analyzed by scholars, including Eve Warburton who called Jokowinomics as a new form of developmentalism. Her definition of "new developmentalism' derives from differentiating between the ideal developmentalist ideas and the repressive development model. The ideal developmentalist ideas refers to the development approach in Japan, Taiwan and South Korea in post-World War II era with fast-paced industrialization and significant portion of state intervention. On the other hand, there existed a repressive development model back in 'New Order' regime under President Soeharto's dictatorship. ${ }^{8}$ She argued the 'new developmentalism' is neither of those models. Instead, the developmentalism that emerges in Jokowi's era is best described as pursuing fast development to overcome backwardness and catch up with advanced countries, subordinating other political goals to the overarching aim of achieving rapid economic growth. ${ }^{9}$ It is said to also be conservative, by the aversion of politically sensitive problems such as law reform, corruption and good governance that could jeopardize the stable climate which eventually may hinder growth. Commitment to these development agendas result into narrow, pragmatic economic policy goals. ${ }^{10}$ Warburton's literature had deeper focused on answering the why's of the topic by analyzing Jokowi's political maneuver in achieving the political stability and majority voice he didn't have during the early days of his cabinet.

A similar argument was also presented by Fredick Broven Kayanta in discussing about the discourse factors in Jokowi's infrastructure development plan. Kayanta argued that Jokowi's first-term presidency saw an overly-hegemonic discourse on infrastructure development that triggered antagonism from civil society and intellectual groups by disregarding any clear resolution towards human rights issues. ${ }^{11}$ Paul J. Burke also challenged the material-oriented development in one of his

\footnotetext{
${ }^{6}$ Ibid.

${ }^{7}$ Ian Morse, 2019, "Indonesia aims for the fastest growth in Jokowi’s term," The Diplomat, August 28, https://thediplomat.com/2019/08/indonesia-aims-for-fastest-growth-of-jokowis-term/

${ }^{8}$ Eve Warburton, 2016, "Jokowi and the New Developmentalism," Bulletin of Indonesian Economic Studies, 52:3, p.307, DOI: 10.1080/00074918.2016.1249262.

${ }^{9}$ Ibid.

${ }^{10}$ Ibid.

${ }^{11}$ Frederick Bowen Ekayanta, 2019,'Ideology and Pragmatism: Discourse Factors in Infrastructure

Development in Indonesia's Jokowi-JK Era,” Jurnal Politik Vol.4, No.2, DOI: 10.754/jp.v4i2.229.
} 
literatures, stating that the current development plan should focus more on the inclusivity and the protection of marginalized societies. ${ }^{12}$

The existing literatures have acknowledged that Jokowi's developmental agendas have been dominated by pragmatic and materialistic agendas on economic growth and discounts other agendas that are supposed to be as urgent in the society in the process. This paper will try to fill the gap by being more specific, by assessing the existing development plan in Jokowi's first term with its impacts and implications towards the progress of Indonesian civil rights protection as one of Indonesia's commitment in attaining SDGs. On another important note, as this paper will argue that the current development strategy is not enough for liberating Indonesian society holistically, it will not try to nullify the benefits of infrastructure boom and economic growth. Instead, this paper will argue on the needs to have a better account on human rights liberalization in Jokowi's development agendas. Although it might be challenging to conclude that there is a direct causal relationship between infrastructure development and protection of civil rights, it is important to realize that repercussion of policy implementations are multidimensional in nature. This leads to the need of an assessment towards the fields affected, which will remained untouched if we keep using the same traditional lenses of growth. Furthermore, this paper aims to show that there needs to be a wider focus when we approach developmental ideas for Indonesia. To depict this argument clearly, this paper will use a qualitative method to gather data from sources such as political speeches, mass media and related literatures. Other than that, this paper will lay the groundwork on the thinking of Amartya Sen in Development as Freedom that will be elaborated below.

\section{Development as Freedom}

Amartya Sen defines freedom as a process of expanding the real freedoms that people enjoy. Conventional and traditional approach to development that is either by identifying progress of development through the growth of gross national product, the rise of personal incomes, industrialization, or technological advance, is simply too narrow and insufficient. ${ }^{13}$ As much as all of those can serve as very important indicator, it should be treated simply as means to expand the freedoms enjoyed by society. ${ }^{14}$ This is due to the fact that we despise poverty not due to the lack of income per se, but on how the lack of income denies us from accessing means of other things that can grant us our freedom; be it politically, economically or socially. Therefore, human freedoms should become the central detrimental factors of developmental strategy where it is not only the primary ends of development, but should also become the principal means of it. Sen sees that the conventional approach relies heavily on the perspective of utilitarianism that attaches no intrinsic importance to claims of rights

\footnotetext{
12 Paul J. Burke and Martin D. Sirayanamual, 2019, “No one left behind in Indonesia?” Bulletin of Economic Studies, 55:3, 269-293, DOI: 10.1080/00074918.2019.1690410.

${ }^{13}$ Amartya Sen, 2000, Development as Freedom, New York: Alfred A. Knopf, Inc. p. 3

${ }^{14}$ Ibid.
} 
and freedoms. Instead, these claims of rights and freedoms are valued indirectly and only to the extent of their influence utilities. ${ }^{15}$ Although taking notes of happiness is sensible, being a happy slave is of course not an ideal or desired condition. Such approach on utilitarianism, according to Sen, has caused people all around the world still suffer from varieties of 'unfreedom' despite the dominating optimistic discourse on market and economic growth. These unfreedoms include famines, inaccessibility of healthcare and education, to gender inequality that greatly plunders women from their capabilities to obtain substantive freedom.

Specifically, Sen identifies five types of freedoms; political freedom, economic facilities, social opportunities, transparency guarantees and protective security. ${ }^{16}$ These key points are called 'instrumental freedoms' as they tend to contribute to the general capability of a person to live more freely, and are interconnected and complementary to each other where they may greatly help one in advancing freedom of other types. ${ }^{17}$ Political freedoms relate to those called civil rights, which is the main focus of this paper. It is broadly conceived as the opportunity to determine who should govern and on what principles, to include the opportunity to scrutinize and criticize authorities, to have freedom of political expression and an uncensored press, and so on. ${ }^{18}$ As they are interrelated and influential to the existence of each other, political freedom is one of the most basic entitlement that enacts as a voice to guarantee the access to other forms of freedom, hence the importance.

Systematical deprivation of political liberty and basic civil rights deny the people from many other forms of security, including prevention of famines or other economic disasters in which a working democracy should provide. ${ }^{19}$ However, Sen noted an important clarification that political liberty and basic civil rights should be directly essential on their own, and do not have to be justified in terms of their practical outcome on economy. Political and civil rights are important as they give people sovereignty to lead their lives and take part in the public affairs that affect them at the end of the day. Since these freedoms are constitutive elements of human freedom, their denial is a handicap itself. Meaning, their plunder in exchange for rapid economic growth, or any alleged advantages in promoting economic development would never be acceptable, and any approach that wants to justify any means for the ends while sacrificing people's sovereignty in form of their political liberty and civil rights in the process is simply a false claim in default. This premise on the importance of political liberty and civil rights is crucial for readers to grasp before we dive into the arguments that will be presented below, as we will finally see how the development strategy of Indonesia can't simply put away or discount any civil liberty of Indonesian people for the sake of graphs and numbers of growth.

In order to identify on whether the instruments of freedom are available, Sen uses two facets of measures: processes that allow freedom of actions and decisions, and the actual opportunities that

\footnotetext{
15 Ibid, p.62.

${ }^{16}$ Ibid, p.36-38.

${ }^{17}$ Ibid, p.37.

${ }^{18}$ Ibid, p.39.

${ }^{19}$ Ibid, p. 16.
} 
people have as the result of their personal and social circumstances. ${ }^{20}$ To create distinction between these two, Sen noted on the importance of seeing freedom in a broad way, where we take concerns about the appropriate procedures; the nature of the processes that bring the opportunities to the freedom of choice people have, and the adequate opportunities that people should have substantively earned as humans, in order to see what kind of capability deprivation that occurs at the consequence of the process. ${ }^{21}$ More specifically in his more established work on the operationalization of the theory, in Rationality and Freedom, Amartya Sen proposed to analyze the preference of individuals and societies (both can be independent from each other, yet they sometimes mirror one another) and compare it with the reality of capabilities people enjoy to obtain those preferences. ${ }^{22}$ These facets will be later used as the tool to operate the analysis presented below, as this paper's take on the process will be centered around the policies and the violation of procedures that finally take away the actual opportunities people are supposed to have at hand.

In regards to the current system dominated by the market, although he provided criticisms for the system, Sen does not reject all the standard economic argument in favor of the market mechanism. ${ }^{23} \mathrm{He}$ argued that the freedom to access the free market is one of the important contribution for development, acknowledging the access to labor and capital indeed exist at the heart of the free market. However, there needs to be an active scrutinizing from the public towards the market to ensure it can run as competitive as it is accessible for the people. He argued that to enable society in enjoying the benefits of development, there is a need to develop and support the plurality of institutions that include democratic and legal system, market structure, educational and health provisions, media access and so on. ${ }^{24}$ The institution can incorporate private initiatives and public arrangements to make it happen. ${ }^{25}$ In other words, Sen does not stand on a rigid structure of the operations of development and realized the multidimensional nature of our current system as well as the potential of each actors involved in pursuing the ideal development.

Conclusively, the set of ideas Amartya Sen presented in Development as Freedom calls for human development to be placed at the center of the stage. It should be treated both as means where instrumental freedom is essential to provide greater extent of freedom, yet at the end this human development will make a direct contribution to the expansion of human capabilities and the quality of life. Increase in quality and equity of healthcare, education, social security, etc. directly affect the quality of life and its flourishing. ${ }^{26}$ In macro level, a country that can guarantee these instruments before all material inducing development plan (infrastructure boom, for instance) can actually achieve

\footnotetext{
${ }^{20}$ Ibid, p.17.

${ }^{21}$ Ibid.

${ }^{22}$ Amartya Sen, 2002, Rationality and Freedom, Cambridge: Harvard University Press, p. 620-654.

${ }^{23}$ Bertil Tungodden, 2001, Balanced view of Development as Freedom, CMI Working Papers (WP) 2001:14, p.14.

${ }^{24}$ Amartya Sen, Development as Freedom, p. 53.

${ }^{25} \mathrm{Ibid}$

${ }^{26}$ Ibid, p.144.
} 
remarkable results in terms of the length and quality of life of the entire population. Finally, it opens up chances to impact the productivity of people, and economic growth on a widely shared basis. Thus, the idea presented by Amartya Sen is not in a world of binary, where we have to choose between human freedom and economic growth. Instead, he argued that when we prioritize human development and the expansion of their freedom is when we can achieve the most of the development, in terms of its quality and its sustainability. Understanding this concept by Amartya Sen will be useful in assessing the current existing Indonesian developmental plan as well as its future trajectory, on whether it has fulfilled the main potential of human freedom, specifically their civil rights, to result in a sustainable growth instead of mere optimistic numbers on quarterly reports.

\section{Jokowinomics and Its Ambitious Plan}

In August 2016, Jokowi delivered a state-of-the-nation address and proclaimed acceleration of national development. The speech was heavily nuanced on domestic issues, particularly on infrastructure, with very limited spotlight on foreign policy, democracy and justice system. ${ }^{27} \mathrm{He}$ laid out his ambitions to deliver 35,000 watts of electricity, develop five port hubs and 19 feeder ports, build 3,650 kilometers of new roads and achieve $100 \%$ access to clean water nationwide. ${ }^{28}$ To realize this, he provided bigger funding in infrastructure sector. In comparison to his predecessors which was only budgeted for 9.48\% in SBY's presidency, Jokowi's term reached $14.46 \%$ of the state budget. Other than that, the famous un-populist policy of decreasing the fuel subsidy from Rp 276 trillion to Rp 64.67 trillion was done to provide a capital injection to state-owned enterprises, and infrastructure development. ${ }^{29}$ By 2018, the administration managed to build 3,432 km of national roads, $947 \mathrm{~km}$ of toll roads, $39.8 \mathrm{~km}$ of bridges, 134 suspension bridges, $754.59 \mathrm{~km}$ of railway lines, 10 airports, 19 ports and 17 dams. ${ }^{30}$ Although still far from the initial goal, there had been promising progress of the infrastructure development.

Assuming the second term, Jokowi also maintained the same spirit but with additional focus on human capital development, acknowledging the lags and unpreparedness in facing the international competition. To this, approximately Rp 506 trillion from the state budget is allocated for education funds. Furthermore, his ambition for the second term included the simplification of bureaucracy, where he promised easier entry point for business in Indonesian market. This is realized through the muchdebated Omnibus Law that was marketed for employment creation and investment invitation that have been rejected by Labor Unions.

\footnotetext{
${ }^{27}$ Eve Warburton, "Jokowi and the New Developmentalism,"

${ }^{28}$ Ibid.

${ }^{29}$ Frederick Bowen Ekayanta, Ideology and Pragmatism, p.306-307.

${ }^{30}$ Wilmar Salim and Siwage Dharma Negara, 2018, "Infrastructure Development under the Jokowi

Administrations: Progress, challenges and policies," Journal of Southeast Asian Economies Vol. 35 Issue 3, p. 255
} 
The rationales of Jokowi's ambitions behind these mega projects of infrastructure was acceptable. The government saw that infrastructure is the basic capital to move forward and the development must be done soon to avoid bigger loss in the future. Indonesia had lagged of infrastructure as results of the previous administrations deficiencies in the system and had caused Indonesia in uncompetitive advantage when compared to the developed countries. ${ }^{31}$ As the administration marketed the infrastructure boom as pro-poor policies, we have seen progress in the reduction of people living under the national poverty line, which counts for $9.4 \%$ per February 2020 in comparison to the doubledigit rate of $11.25 \%$ at the start of the first-term presidency. ${ }^{32}$ Acknowledging this achievement is essential to show where this paper stands, where we are not arguing against the concept of infrastructure development per se, but more in the way the administration frames it as the only important thing to see and shutting off the spotlight from other if not more, equally pressing issues. Hence, it's crucial to analyze the implications of this narrow focus towards the agenda of civil rights liberty for Indonesian people which will be discussed in the next part.

\section{The Stagnation in the Fight for Civil Rights Liberty in Indonesia}

Referring to Amartya Sen's ideas of development, human freedom should be put at the central part of the plan. This part will assess Indonesian developmental plan during Jokowi's first term and his ongoing second term (after having established they are on similar trajectories in the previous part) on whether the policies and plans can grant better civil rights protection for Indonesian people. The analysis will be divided into the process and the actual opportunity as the method to assess the availability of civil rights protection for Indonesian people.

Analyzing the process, as referred to Amartya Sen's operationalization method, requires scrutiny on the policies on the macro level to discover systematic violation of procedures that will eventually affect the opportunities of people on the ground. Relating to this, Jokowi's presidency in the first term can serve a legitimate claim of a pattern of democratic decay, which arguably one of the most detrimental factors to indicate a civil rights liberty. Quantifiably, Indonesia democracy index has experienced the second lowest score of the decade in 2019 , scoring only by 6.4 and placed $64^{\text {th }}$ position out of 167 countries, in comparison to the starting point of 6.9 in $2014 .{ }^{33}$ The index was published by Economist Intelligence Unit (EIU) that is based on five indicators; electoral process, pluralism, government functions, political participation, political culture and civil liberties. ${ }^{34}$ Other than quantification, this part will go to a further extent to analyze the policies formed during Jokowi's

\footnotetext{
${ }^{31}$ Ibid.

${ }^{32}$ Redi Sunarta, 2019, “Indonesia’s Poverty Profile” Towards Data Science, Aug 15, https://towardsdatascience.com/indonesias-poverty-profile-6f53b14def0f

${ }^{33}$ Karina M. Tehusijarana, 2020, "Indonesia, once regional model, falls further behind Malaysia in democracy rankings," The Jakarta Post, January, 22, https://www.thejakartapost.com/seasia/2020/01/22/2019-eiudemocracy-index-shows-indonesia-falling-further-behind-malaysia.html ${ }^{34}$ Ibid.
} 
presidency to prove that democratic decay happens in a qualitative manner. Analyzing the democratic nature is necessary as the 'process' from Amartya Sen's idea, which is to acknowledge that democracy is an important enabler (or disabler, if lack thereof) for people to have a voice and fight for their civil rights.

First, we take a look on the structure of his presidency that will affect the whole decisionmaking process. It is notable that Jokowi's win in 2014 was thought to be a breath of fresh air to Indonesian oligarchic politics. Being a political outsider, Jokowi's rise from being a mayor of the City of Solo, then later the governor of the capital, had framed him as a challenge to the oligarchic rule. His down-to-earth leadership was widely celebrated where we could see massive grass-root voluntarism emerged to show support for his candidacy. However, a year into his winning, the celebration turned into disappointment, as we saw Jokowi's transactional politics and clientelist pattern when he tried and succeeded in building a big-tent party coalition for his cabinet, ${ }^{35}$ trying to secure as much support as possible for the sake of political stability. The consolidation of the political power resulted in significant decrease of opposition minority, from just $37 \%$ seats in parliament to $69 \%$ majority in $2016 .{ }^{36}$ Showing an arguably little significance in reforming the political dynasty, long gone was the image of a clean and reformist president. Instead, Jokowi was closer to the image of politics of accommodation and vested interests of the same old figures. ${ }^{37}$ Understanding this context is important to contextualize the structural formation of the government and how it affects the quality of democracy, where his hard-won political equilibrium may finally grant him a 'conducive' political climate for his infrastructure ambitions, and in exchange, the mechanism of check-and-balance which is essential in democracy might be harmed in the longer term.

The political climate in Jokowi's presidency has also witnessed a momentous growth of divisiveness and the rise of identity politics, evidently since the 2017 Jakarta Gubernatorial election that imprisoned Basuki Tjahaja Purnama (or familiarly known as Ahok) with alleged religious blasphemy, which effect lasted until the latest presidential election in $2019 .{ }^{38}$ The antagonism and the phenomenon of Islamic populism has been observed to be on the rise, hence decreasing the degree of tolerance towards the plural nature of Indonesian society which may play as one of the factors in the weakening of our democracy index. ${ }^{39}$ This characterization is visible through the courses of events leading up both to the election in 2017 and 2019 where mega mass movement such as 411 and 212 occurred with their divisive messages between those of conservatives and pluralists. The religious polarization with heavy

\footnotetext{
${ }^{35}$ Yuki Fukuoka and Luky Djani, 2016, "Revisiting the rise of Jokowi: The triumph of reformasi or an oligarchic adaptation of post-clientelist initiatives" Southeast Asia Research Vol 24(2): 204-221

${ }^{36}$ Eve Warburton, p.298-299.

${ }^{37}$ Jokowi has been surrounded with strong figures from the Suharto era, such as Wiranto and Luhut Panjaitan who are positioned in strategic functions in his cabinet for two terms in a row.

${ }^{38}$ Read more on Charlotte Setijadi, "Ahok's Downfall and the Rise of Islamist Populism in Indonesia," ISEAS Perspective Issue 2017, No.38, June 2017.

${ }^{39}$ Read more on "Anti-Ahok to Anti-Jokowi: Islamist Influence on Indonesia's 2019 Election Campaign," IPAC Report No. 55, March 15, 2019.
} 
sectarian messages that color most of the political process in Indonesia has created a new challenge for pluralist candidates in winning their electorates. ${ }^{40}$ This is one of the process aspects that is referred by Sen which poses as one of the institutional challenges that hinders the substantive rights of pluralism for Indonesian people.

Going deeper into the policies, Jokowi's presidency has produced notable bills that affect the institutional capability of the government in pursuing a transparent and accountable government which inevitably has consequences over the procedure of civil rights protection. One of the most disputed bill that triggered one of the biggest mass protests in 2019 was the revision of the bill for Komisi Pemberantasan Korupsi (KPK) or Commission for Corruption Eradication. ${ }^{41}$ The bill was believed to weaken the independence and authority KPK previously had to fight against the corrupted elites as it was going to be under the supervision of a governmental body. Media and scholar critics called the revision as a disastrous assault towards the democracy for its secretive nature in the process of drafting and passing the bills, and how it ignored society's response and aspiration by ratifying the bill eventually. ${ }^{42}$ Along with the KPK bill, revision for a new criminal code (RKUHP) was also widely rejected amongst the protesters as the new bill will criminalize actions that are considered as breach of privacy, including extramarital sex, abortion to insulting the president. ${ }^{43}$ Furthermore, there are many alleged cases of police excessive violence towards the protesters at that time that receive no clear solvency as of time of writing in March $2020 .{ }^{44}$ These two major regulations indicate a growing trend of shutting down public opinion, as government limited the platform of expression for the people through police force or by simply establishing such system that actually overlooks public opinion. This became a violation of procedure that limited the substantive rights of people to determine the trajectory of government as supposedly given by the democratic principles the country held on to. As results, the opportunity aspect of people to enjoy the freedom, one of them being freedom of expression is deprived and disabled by the existing process.

Another case study relating to the argument is the ongoing debate on Omnibus Law. The law covers the employment issue that is marketed by the government to ease business and to incentivize

\footnotetext{
${ }^{40}$ Thomas P. Power, 2018, Jokowi's authoritarian turn and Indonesia's democratic decline, Bulletin of Indonesian Economic Studies, 54:3, 307-338, DOI: 10.1080/00074918.2018.1549918

${ }^{41}$ Komisi Pemberantas Korupsi (KPK) is a used-to-be independent institution to fight corruption within governmental bodies and actors, popular for its Operasi Tangkap Tangan, roughly translated to immediate arrest that caught the corruptors off guard to be proceeded to law enforcement.

${ }^{42}$ Editorial Board, 2019, "Legislative assault on KPK," The Jakarta Post, September 18, https://www.thejakartapost.com/academia/2019/09/18/legislative-assault-on-kpk.html

${ }^{43}$ Kate Lamb, 2019, "Thousands protest against the new criminal code across Indonesia," The Guardian, September 24, https://www.theguardian.com/world/2019/sep/24/thousands-protest-against-new-criminal-codeacross-indonesia

${ }^{44}$ Read more on Kharishar Kahfi, 2020, "2019 saw rise of new resistance after Indonesia failed to protect rights: Amnesty," The Jakarta Post, January 30, https://www.thejakartapost.com/news/2020/01/30/2019-saw-rise-ofnew-resistance-after-indonesia-failed-to-protect-rights-amnesty.html
} 
foreign capital to invest in the country. ${ }^{45}$ The law is often summed up to "flexible working hours, easy firing and easy hiring" that is set to apply during Jokowi's second term. ${ }^{46}$ The draft invited rejection and constant mass demonstrations from the civil society, in particular the labor unions that interpret the new regulation will threaten job security of Indonesian workers and loose regulations the foreign employment which is not ideal for Indonesia's booming productive population. Again, this regulation has the similar nuance on creating a pro-business law that is pragmatic to boost up growth and capital for the country development but harmful to those in the grass root level.

Minority and specific marginalized group have also experienced inadequacy of protection for their civil rights liberty. Crackdown on Papua that includes internet shutdown which sparked a national controversy, can be a representative case study. The separatist movement in West Papua is not a new phenomenon where it includes complex history that traces back to Indonesia's post-independence era in 1945. However, when Jokowi came to power in 2014, he promised a new approach to resolve the ever-present grievances of Papuans. To achieve this, he built inroads and infrastructure to promote connectivity and accessibility for Papua, with Trans-Papua as one of his flagship project. In the report of his 4-years progress of his first term that was published by Badan Kependudukan dan Keluarga Berencana Nasional (BKKBN) also highlighted on the success of infrastructure development in Papua and the economic productivity that increased as the result. ${ }^{47}$ However, alongside to the infrastructure development, there were 69 extrajudicial killings occurred in Papua with 10 foreign journalists arrest in the period of Jokowi's supposedly new resolve methods. ${ }^{48}$ Notably, 24 construction workers in the eastern part of Papua have also been killed by unknown gunmen after embarking on separatist movement related celebrations in December 2018. The development and resolution of this case remain undiscovered as independent media have suffered from strict limitations of access to the news of the region. ${ }^{49}$ Furthermore, September 2019 saw a new conflict escalation with a nation-wide protest after alleged attack and racial sentiments that are directed towards the Papuans. Jokowi's response to the conflict was particularly problematic towards the aspect of political freedom of the people, where internet shutdown and police violence methods were used to silence the Papuan grievances. This particular case study has shown that there is a significant defect in the process aspect, where Jokowi took a narrow approach of building infrastructures while leaving the human rights violation issues to continue. Furthermore, the pattern of governmental response to conflicts happening in Papua have shown a structural hindrance towards the protection of Papuans. This process aspects result in a

\footnotetext{
45 Jefferson Ng, 2020, “Jokowi's Macron Moment: Moving together or moving fast?” New Mandala, January

29, https://www.newmandala.org/jokowis-macron-moment/

${ }^{46}$ Ibid.

${ }^{47}$ BKKBN, 2018, "Laporan 4 Tahun Pemerintahan Joko Widodo - Jusuf Kalla," available on https://www.bkkbn.go.id/po-content/uploads/Laporan-4-Tahun-Jokowi-JK.pdf

${ }^{48}$ Friski Riana, 2018, "KontraS: Human Rights Issues Not Priority for Jokowi-JK," Tempo, October 20, https://en.tempo.co/read/922704/kontras-human-right-issues-not-priority-for-jokowi-jk

49 2018, Indonesia attack: Gunmen kill 24 construction workers in Papua," BBC, December 20, https://www.bbc.com/news/world-asia-46446719
} 
deprivation in the freedom of expression, especially with structural violence and the internet shutdown policy. Media restriction also has limited the freedom of access to information for Papuans, which is one of the most fundamental civil rights to bear.

Although development and civil rights are not supposed to be exclusionary from one another, Jokowi administration is seemingly treating them otherwise by prioritizing the former and discounting the latter. The pattern of regulation making in Jokowi's era has been proven to pose a structural challenge in regards to ensuring a conducive procedure in granting substantial political freedom or civil rights for Indonesians. This challenge then affected the capability deprivation for Indonesians in terms of enjoying their civil rights, where we see attempts on limiting or ignoring voices from grass-root level hence depriving them of their freedom to express and to be involved in the policy making. We also see the rise of identity politics that deprive people of their capability to access plural political climate which is important given Indonesian plural background. More explicit of capability deprivation visible in cases of minority persecution in the case of Papua, where their freedom of expression, self-determination and access to information are structurally made unavailable due to the deficiencies of process.

\section{Conclusion}

The way for Jokowi to approach development for Indonesia is indeed distinct. It prioritizes capital injection, skyscrapers, highways, etc. to achieve promising numbers of growth and productivity, which at first glance was prospective and optimistic. However, the dominating discourse on this approach, and this approach only, poses a trade-off for the civil rights liberty of Indonesians, where sensitive and challenging issues of human rights protection is set aside for the sake of a stable economic climate that is appealing to investors. This narrative of development then, is the traditional perspective of development that Amartya Sen concerned about in his thinking of Development as Freedom, where material and pragmatic goals of growth is treated as an end of itself, instead of means to achieve a greater freedom for the people. As the process and opportunity aspect of Indonesian political freedom have been proven as deficient after analyzing major case studies of human rights violation in Jokowi's term, it can be concluded that the narrow and pragmatic agenda is not enough for reaching a sustainable benefit of development. There is an urgency for Jokowi's administration to reevaluate on the current approach of development where shining portfolio investments is currently treated as the achievement the administration can brag upon. Instead, it needs to take on the human-centered perspective as proposed by Amartya Sen, where liberation of human rights and granted freedoms for persecuted minorities should have been the worthy celebration of the administration. As Jokowi is living his second and last term, it is still not too late to create a legacy that can achieve a human development as the key to a sustainable and inclusive growth for Indonesia. 


\section{References}

\section{Books and Journals}

Burke, Paul J. and Martin D. Sirayanamual. 2019. “No one left behind in Indonesia?” Bulletin of Economic Studies, 55:3, 269-293. DOI: 10.1080/00074918.2019.1690410.

Ekayanta, Frederick Bowen. 2019.'Ideology and Pragmatism: Discourse Factors in Infrastructure Development in Indonesia’s Jokowi-JK Era.”Jurnal Politik Vol.4, No.2. DOI: 10.754/jp.v4i2.229.

Fukuoka, Yuki and Luky Djani. 2016. "Revisiting the rise of Jokowi: The triumph of reformasi or an oligarchic adaptation of post-clientelist initiatives.” Southeast Asia Research Vol 24(2): 204-221.

Power, Thomas P. 2018. "Jokowi's authoritarian turn and Indonesia's democratic decline." Bulletin of Indonesian Economic Studies, 54:3, 307-338. DOI: 10.1080/00074918.2018.1549918

Warburton, Eve. 2016. “Jokowi and the New Developmentalism." Bulletin of Indonesian Economic Studies, 52:3. DOI: 10.1080/00074918.2016.1249262.

Salim, Wilmar and Siwage Dharma Negara. 2018. "Infrastructure Development under the Jokowi Administrations: Progress, challenges and policies." Journal of Southeast Asian Economies Vol. 35 Issue 3.

Sen, Amartya. 2000. Development as Freedom. New York: Alfred A. Knopf, Inc.

Sen, Amartya.2002. Rationality and Freedom. Cambridge: Harvard University Press.

Setijadi, Charlotte. "Ahok's Downfall and the Rise of Islamist Populism in Indonesia." ISEAS Perspective Issue 2017, No.38. June 2017.

Tungodden, Bertil. 2001. Balanced view of Development as Freedom. CMI Working Papers (WP) 2001:14.

“Anti-Ahok to Anti-Jokowi: Islamist Influence on Indonesia's 2019 Election Campaign.” IPAC Report No. 55. March 15, 2019.

\section{Official Documents}

BKKBN. 2018. "Laporan 4 Tahun Pemerintahan Joko Widodo - Jusuf Kalla.” Available on https://www.bkkbn.go.id/po-content/uploads/Laporan-4-Tahun-Jokowi-JK.pdf

Komnas HAM. "Tujuan 16." in Kerangka Analisis untuk Mengintegrasikan Tujuan Pembangunan Berkelanjutan (SDGs) dengan Kewajiban Pemenuhan Hak-hak Asasi Manusia untuk di Indonesia. Available in komnasham.go.id.

"Progress of Goal 16 in 2019." SDG Knowledge Platform. https://sustainabledevelopment.un.org/sdg16

“Indonesia's Commitment to Sustainable Development: 2030 Agenda for Sustainable Development." Kementrian Luar Negeri Republik Indonesia. 
https://indonesia4unsc.kemlu.go.id/index.php/our-priorities/indonesia-s-commitment-tosustainable-development

\section{Online Media}

2018. "Indonesia attack: Gunmen kill 24 construction workers in Papua.” BBC. December 20. https://www.bbc.com/news/world-asia-46446719

Cheston, Timothy. "Indonesia and the Quest for 7\% Growth: Overpromise or Underperformance?" Atlas of Economic Complexity Harvard, https://atlas.cid.harvard.edu/stories/indonesia/

Editorial Board. 2019. "Legislative assault on KPK." The Jakarta Post. September 18. https://www.thejakartapost.com/academia/2019/09/18/legislative-assault-on-kpk.html

Kahfi, Kharishar. 2020. “2019 saw rise of new resistance after Indonesia failed to protect rights: Amnesty." The Jakarta Post. January 30.

https://www.thejakartapost.com/news/2020/01/30/2019-saw-rise-of-new-resistance-afterindonesia-failed-to-protect-rights-amnesty.html

Lamb, Kate. 2019. "Thousands protest against the new criminal code across Indonesia." The Guardian. September 24. https://www.theguardian.com/world/2019/sep/24/thousands-protestagainst-new-criminal-code-across-indonesia

McCawley, Peter. 2019. “Jokowi bets on an infrastructure boom.” East Asia Forum. April 10. https://www.eastasiaforum.org/2019/04/10/jokowi-bets-on-an-infrastructure-boom/

Morse, Ian. 2019. "Indonesia aims for the fastest growth in Jokowi's term." The Diplomat. August 28. https://thediplomat.com/2019/08/indonesia-aims-for-fastest-growth-of-jokowis-term/

Ng, Jefferson. 2020. “Jokowi’s Macron Moment: Moving together or moving fast?” New Mandala. January 29. https://www.newmandala.org/jokowis-macron-moment/

Riana, Friski. 2018. “KontraS: Human Rights Issues Not Priority for Jokowi-JK.” Tempo. October 20. https://en.tempo.co/read/922704/kontras-human-right-issues-not-priority-for-jokowi-jk

Sunarta, Redi. 2019. “Indonesia’s Poverty Profile.” Towards Data Science. Aug 15. https://towardsdatascience.com/indonesias-poverty-profile-6f53b14def0f

Tehusijarana, Karina M. 2020. "Indonesia, once regional model, falls further behind Malaysia in democracy rankings." The Jakarta Post. January, 22. https://www.thejakartapost.com/seasia/2020/01/22/2019-eiu-democracy-index-showsindonesia-falling-further-behind-malaysia.html 